\title{
Gene expression of the insulin-like growth factor system during mouse kidney development
}

\author{
Dicky J. Lindenbergh-Kortleve *, Roberto R. Rosato, Johan W. van Neck, Jeroen Nauta, \\ Marjolein van Kleffens, Cora Groffen, Ellen C. Zwarthoff, Stenvert L.S. Drop \\ Department of Pediatrics, Subdivision of Molecular Endocrinology, Subdivision of Pediatric Nephrology and Department of Pathology, \\ Erasmus University Rotterdam, Rotterdam, The Netherlands
}

Received 30 April 1997; accepted 16 June 1997

\begin{abstract}
Expression of the insulin-like growth factor (IGF) system was investigated in mouse renal development and physiology, using non radioactive in situ hybridization and quantitative RT-PCR. IGF-I mRNA levels increased after birth and were confined to distal tubules and peritubular capillaries in the outer medulla. IGF-II mRNA levels were high in developing kidneys and peaked after birth. The type I receptor mRNA expression pattern mostly parallelled those of IGF-I and IGF-II. The IGF binding proteins (IGFBP's) showed weak mRNA expression for IGFBP-1 and -6. High fetal mRNA levels were measured for IGFBP-2, showing a similar profile in time as observed for IGF-II. Low fetal IGFBP-3 and -5 mRNA levels increased after birth. IGFBP-2, - 4 and -5 mRNA expression was localized to differentiating cells. In the mature kidney predominant expression was confined to proximal tubules (IGFBP-4), thin limbs of Henle's Loop (IGFBP-2), glomerular mesangial cells (IGFBP-5) and peritubular capillaries of the medulla (IGFBP-5). IGFBP-3 mRNA was exclusively expressed in endothelial cells of the renal capillary system. Distinct mRNA expression for each member of the IGF system may point to specific roles in development and physiology of the mouse kidney. (O) 1997 Elsevier Science Ireland Ltd.
\end{abstract}

Keywords: Development; Mouse kidney; IGF; IGFBPs; mRNA expression

\section{Introduction}

The development of the kidney is based on morphogenic processes that evolve in a sequential manner. After an inductive interaction of the epithelial cells of the ureter and the mesenchymal cells of the metanephros, both cell types start to proliferate and differentiate, finally leading to the formation of glomeruli and renal tubules (Saxen and Sariola, 1987).

A number of polypeptide growth factors are involved in renal organogenesis. Epidermal growth factor

\footnotetext{
* Corresponding author. Department of Pediatrics, Subdivision of Molecular Endrocrinology, Room Ee 1022, Erasmus University Rotterdam, Rotterdam, PO Box 1738, 3000 DR Rotterdam, The Netherlands. Tel.: + 311 4087936; fax: + 3114366660 .
}

(EGF), transforming growth factors (TGFs), fibroblast growth factors (FGFs), platelet-derived growth factors (PDGFs) and insulin-like growth factors (IGFs) have been described in developmental studies for their regulatory roles in morphogenesis (Hammerman, 1995). Both IGF-I and IGF-II are single chain polypeptides which have mitogenic and differentiating effects on many cell types. IGF action is predominantly mediated through the type I receptor and the availability of the IGFs for the receptor is thought to be regulated by the IGF binding proteins (IGFBPs).

The kidney is an obvious target of IGFs. In addition to circulating IGFs, local synthesis implies paracrine and autocrine IGF action as well. In the mature kidney IGFs can alter proximal tubular transport processes (Mellas et al., 1986; Rogers and Hammerman, 1989; Quigly and Baum, 1991; Caverzasio et al., 1990), stimu- 
late vectorial $\mathrm{Na}^{+}$transport (Blazer-Yost and Cox, 1988; Blazer-Yost et al., 1989) and control glomerular filtration rate and renal plasma flow levels (Hirschberg et al., 1991, 1993).

IGF-I and IGF-II have been detected in rat metanephroi (Rogers et al., 1991) and abundant IGF-II expression was found in epithelial and mesenchymal cells of the nephrogenic zones in man (Matsell et al., 1994). IGF-I expression was more prominent after development, mainly confined to the thick ascending limbs of Henle's Loop in both rat and man (Chin et al., 1992; Rabkin et al., 1995). The type I IGF receptor is expressed in the rat mesonephros during early embryogenesis (Bondy et al., 1990) and blocked expression in mouse kidney organ cultures (Liu et al., 1993) has demonstrated its relevance in nephrogenesis. After development the type I receptor is widely distributed in kidney of rat (Chin et al., 1992; Rabkin et al., 1995) and man (Chin et al., 1994; Chin and Bondy, 1992).

Six mouse IGFBPs have been cloned (Schuller et al., 1994), each of them showing specific expression patterns during embryonic development (Schuller et al., 1993). During development of the human kidney abundant expression is seen for IGFBP-2 and -4 in nephrogenic zones and epithelial cells of the maturing glomerulus, while moderate expression is seen for IGFBP-3 in epithelial cells of the ureteric bud and for IGFBP-5 in originating mesenchymal cells (Matsell et al., 1994). In the mature rat kidney glomerular and tubular expression is described for IGFBP-2 and -4 , where as IGFBP- 3 and -5 were mainly interstitially expressed (Rabkin et al., 1995; Price et al., 1995). Low expression of IGFBP-1 is found in the adult human kidney (Chin et al., 1994), while it has been well detected in the thick ascending limbs of Henle's Loop in rat (Chin et al., 1992; Rabkin et al., 1995; Price et al., 1995). The discrete. spatial and temporal expression patterns of the IGFBP genes in kidney support their modulatory role in IGF action.

To study kidney pathophysiology mouse models are often used. We therefore aimed in this study to examine the involvement of the IGF system in normal mouse kidney development. A non radioactive in situ hybridization technique was performed in order to precisely localize the mRNAs of the IGF system in mouse fetal and postnatal kidneys. Total mRNA content for IGF-I, IGF-II, IGFBP-2,3 and -5 in fetal and early postnatal kidneys was determined by quantitative RT-PCR. Combining both techniques resulted in a detailed description of the gene expression of the IGF system during mouse kidney development.

\section{Materials and methods}

The experimental procedures reported in this study were carried out in accordance with the Dutch Animal and Experimentation Act after approval was granted by the Ethical Committee on Animal Experimentation of the Erasmus University Rotterdam.

\subsection{Tissue isolation}

Kidneys were collected from BALB/c mice on fetal day E13, 14, 15, 17, 19 and postnatal day $\mathrm{P} 0,1,3,7$, 14. They were either stored in $-80^{\circ} \mathrm{C}$ for total RNA extraction or fixed in $4 \%$ paraformaldehyde, dehydrated and embedded in paraffin according to standard procedures. For in situ hybridization, $4 \mu \mathrm{m}$ sections were cut on a microtome and mounted on 3aminopropyl trioxysilane-coated slides. Sections were dried at $37^{\circ} \mathrm{C}$ for 3 days.

\subsection{Probe preparation}

The IGFBP-2 to -6 cRNA probes were transcribed from templates described by (Schuller et al., 1994). As template for the IGFBP-1 cRNA probe the mouse cDNA fragment Sph1-Sac1 was cloned into pTZ18R or pTZ19R (Pharmacia, Uppsala, Sweden) for the antisense or sense probes, respectively. cDNAs encoding mouse IGF-I and -II were kindly provided by Dr G.I. Bell (Howard Hughes Medical Institute, Chicago, IL). Fragments were subcloned into pTZ18 and pTZ19 (Eco Rl for IGF-I and Bam Hl/Sac 1 for IGF-II). A 265 bp EcoR1/Sma 1 fragment of the rat type I IGF receptor cDNA clone ligated in pGEM3 (Promega, Madison, WI) was kindly provided by Dr H. Werner and Dr D. LeRoith (National Institutes of Health, Bethesda, MD). Digoxigenin-11-UTP labeled RNA probes were prepared according to the manufacturer's prescription (Boehringer Mannheim GmbH, Biochemica, Mannheim, Germany) using T7 or SP6 RNA polymerase.

\subsection{In situ hybridization}

Sections were dewaxed, hydrated and incubated in the following solutions: $0.2 \mathrm{~N} \mathrm{HCL}, 0.3 \%$ Triton-X 100 in PBS, $5 \mu \mathrm{g} / \mathrm{ml}$ Proteinase $\mathrm{K}\left(37^{\circ} \mathrm{C}\right), 4 \%$ formalin in PBS and finally acetylated with acetic anhydride diluted in $0.1 \mathrm{M}$ triethanolamine $(750 \mu \mathrm{l} / 200 \mathrm{ml})$. Until hybridization sections were stored in a solution of $50 \%$ formamide in $2 \times \mathrm{SSC}$ at $37^{\circ} \mathrm{C}$. For hybridization, probes were diluted in hybridization solution $(50 \%$ deionized formamide, $10 \%$ dextran sulfate, $2 \times \mathrm{SSC}$, $1 \times$ Denhardt's solution, $1 \mu \mathrm{g} / \mathrm{ml}$ tRNA, $250 \mu \mathrm{g} / \mathrm{ml}$ herring sperm DNA) to a concentration of $100 \mathrm{ng} / \mathrm{ml}$, incubated at $68^{\circ} \mathrm{C}$ for $15 \mathrm{~min}$ and layered onto the 
sections. Sections were hybridized overnight at $55^{\circ} \mathrm{C}$ in a humid chamber. Posthybridization washes were performed at $45^{\circ} \mathrm{C}$ using the following steps: $50 \%$ formamide in $2 \times \mathrm{SSC}, 50 \%$ formamide in $1 \times \mathrm{SSC}$ and $0.1 \times \mathrm{SSC}$. A $15 \mathrm{~min}$ incubation with RNase $\mathrm{Tl}$ (2 $\mathrm{U} / \mathrm{ml}$ in $1 \mathrm{mM}$ EDTA in $2 \times \mathrm{SSC}$ ) at $37^{\circ} \mathrm{C}$ was followed by washes of $0.1 \times \mathrm{SSC}$ at $45^{\circ} \mathrm{C}$ and $2 \times \mathrm{SSC}$ at room temperature. The DIG-labeled hybrids were detected by antibody incubation performed according to the manufacturer's prescription (Boehringer Mannheim GmbH, Biochemica, Germany) with following modifications. A 1:2000 dilution of anti-digoxigenin (Fab) conjugated to alkaline phosphatase was used for a $2.5 \mathrm{~h}$ incubation at room temperature. Afterwards an extra washing step of $0.025 \%$ Tween in Tris buffered saline pH 7.5 was introduced. For staining, sections were layered with detection buffer $(0.1 \mathrm{M}$ Tris $-\mathrm{HCl}, 0.1 \mathrm{M}$ $\mathrm{NaCl}, 0.05 \mathrm{M} \mathrm{MgCl}_{2} \mathrm{pH} 9.5$ ) containing $0.33 \mathrm{mg} / \mathrm{ml}$ NBT (4-nitroblue tetrazolium chloride), $0.16 \mathrm{mg} / \mathrm{ml}$ BCIP (5-bromo-4-chloro-3-indolyl-phosphate), 7.5\% PVA (polyvinylalcohol, m.w. 31000-50000 Aldrich Chemical Milwaukee, WI) and $1 \mathrm{mM}$ levamisol (Sigma, St. Louis, MO). The colour reaction was performed in the dark and was stopped when the desired intensity of the resulting blue precipitate was reached. Sections were washed in $10 \mathrm{mM}$ Tris- $\mathrm{HCl}, 1 \mathrm{mM}$ EDTA $\mathrm{pH} 8.0$, counterstained with PAS and Nuclear red solution, dehydrated with ethanol gradients and mounted with an ethanol based mounting medium Euparal (ChromaGesellschaft, Stuttgart, Germany). Control sections for morphological analysis were stained with hematoxylin and eosin.

\subsection{RNA extraction}

RNA preparation was carried out according to the acidic phenol/chloroform method of Chomczynski and Sacchi (1987) from frozen samples conserved at $80^{\circ} \mathrm{C}$. Each time point was represented by a pool of corresponding mouse kidneys. The recovery of total RNA was measured by spectrophotometric analysis at $260 \mathrm{~nm}$ and quality and quantity were verified on a $1.5 \%$ agarose gel. Similar intensities were observed in all samples.

\subsection{Quantitative RT-PCR}

Quantitation of mRNA was done by the non-competitive PCR method described by Pane et al. (1995). An absolute amount of mRNA molecules is calculated by interpolating the generated amount of PCR products from sample RNA into a titration curve obtained by amplifying a known number of synthetic RNA molecules containing the same sequence as the RNA to be quantitated.

\subsubsection{Preparation of standard RNA}

The synthetic mRNA used as standard was obtained in two steps. First, cDNA fragments containing the desired sequences were amplified by performing PCR on the available cDNAs of the mouse IGF system (Schuller et al., 1993). After purification and densitometric quantitation, the fragments were ligated for $3 \mathrm{~h}$ at $15^{\circ} \mathrm{C}$ into the pGEM-T vector (Promega, Madison, WI). This vector contains the T7 promoter sequence and is specially adapted to ligate PCR fragments. A second PCR was performed using $1 \mu 1$ ligation mixture (1:1 diluted) as DNA template, the T7 promoter sequence as 5'-primer (5'- TGTAATACGACTCACTATAGGGAGA-3') and gene specific 3'-primers (Table 1). This strategy resulted in a PCR fragment that contained the same sequence as to be quantitated plus the T7 promoter sequence. This T7-fragment was purified and used for in vitro RNA transcription (RiboMAX kit, Promega, Madison, WI). The produced cRNA was purified by phenol-chloroform extraction and Sephadex G50 column elution. The number of molecules was calculated by using the molecular weight of the cRNA molecule, Avogadro's number and the spectrophotometric absorbance at $260 \mathrm{~nm}$.

\subsection{2. $R T-P C R$}

RT-PCR was performed on both prepared standard RNA and extracted sample RNA One microgram total RNA was reverse transcribed with 200 units of M-MLV reverse transcriptase (Gibco BRL) primed with specific $3^{\prime}$-primers for IGF-I, IGF-

Table 1

Sequences of PCR primers and predicted PCR products

\begin{tabular}{|c|c|c|}
\hline $\begin{array}{l}\text { Amplified mR- } \\
\text { NAs }\end{array}$ & Sense and antisense primers & $\begin{array}{l}\text { Size of amplified } \\
\text { products (bp) }\end{array}$ \\
\hline IGF-1 & $\begin{array}{l}\text { 5'-AAAATCAGCAGTCT- } \\
\text { TCCAAC-3' } \\
\text { 5'-AGATCACAG CTCCG- } \\
\text { GAAGCA-3' }\end{array}$ & 299 \\
\hline IGF-II & $\begin{array}{l}\text { 5'-GCCCCGGAGAGACT- } \\
\text { CTGTGCG-3' } \\
\text { 5'-GCCCACGGGGTATC- } \\
\text { TGGGGAA-3' }\end{array}$ & 253 \\
\hline IGFBP-2 & $\begin{array}{l}\text { 5'-TGGAGGAGCCCAA- } \\
\text { GAAGCT-3' } \\
\text { 5'-GGTTCACACACCAG- } \\
\text { CAACTC-3' }\end{array}$ & 228 \\
\hline IGFBP-3 & $\begin{array}{l}\text { 5'-GCCGCGGGCTCT- } \\
\text { GCGTCAACGC-3' } \\
\text { 5'-CTGGGACTCAGCA- } \\
\text { CATTGAGGAAC-3' }\end{array}$ & 415 \\
\hline IGFBP-5 & $\begin{array}{l}\text { 5'-TTGCCTCAACGAAA- } \\
\text { AGAGC-3' } \\
\text { 5'-AGAATCCTTTGCG- } \\
\text { GTCACA-3' }\end{array}$ & 377 \\
\hline
\end{tabular}


II, IGFBP-2, -3 and -5 (Table 1) in a final volume of 20 $\mu 1$. The PCR reaction was carried out in a final volume of $50 \mu 1$ with the equivalent of $50 \mathrm{ng}$ of total RNA (5 $\mu 1$ of a 1:5 dilution of the Reverse Transcription reaction) in PCR buffer (50 mM KCl, $1.5 \mathrm{mM} \mathrm{MgCl}_{2}$, and $20 \mathrm{mM}$ Tris- $\mathrm{HCl}, \mathrm{pH} 8.3$ ) plus $200 \mu \mathrm{M}$ deoxy-NTPs, $\left[\alpha-\mathrm{P}^{32}\right] \mathrm{dATP}, 25 \mathrm{pmol}$ forward and reverse primers and $1 \mathrm{U}$ of Hi-Taq DNA Polymerase (Bioprobe Systems, France). PCR reactions were performed separately using an initial denaturation at $94^{\circ} \mathrm{C}$ for $3 \mathrm{~min}$, followed by 25 cycles that included: $30 \mathrm{~s}$ at $94^{\circ} \mathrm{C}, 20 \mathrm{~s}$ annealing at $53^{\circ} \mathrm{C}$ (except for IGFBP-2, $45^{\circ} \mathrm{C}$ ) and $30 \mathrm{~s}$ at $72^{\circ} \mathrm{C}$. Products were analysed on a $2.5 \%$ agarose gel and bands corresponding to each specific PCR product were excised and the amount of incorporated radioactivity was determined by $\beta$-scintillation counting. Oligonucleotide primers designed for the amplification were purchased from Pharmacia Biotech (The Netherlands).

\subsection{Statistical analysis}

The differences in expression levels during development were scored for significance using the one-way analysis of variance (ANOVA), followed by a Scheffe $F$ test. Level of significance was chosen at $P<0.05$.

\section{Results}

Development of the mouse kidney starts at fetal day El0 when the ureteric bud emerges and invades the mesenchyme. The resulting appositional development of renal vesicles continues until the early postnatal period. All stages can be recognized in sections of mouse fetal day E15 (staging performed according to Saxen (1987)) and were therefore used to present the expression patterns in developing structures (Fig. 1A,lB). The mRNA expression patterns in mature structures (Fig. 1C) are represented by data from kidneys at postnatal day P14. Scoring based on results from the in situ hybridization of E15 and P14 are listed in Tables 2 and 3, respectively. Results from the RTPCR quantitation are presented in Fig. 5.

\subsection{In situ hybridization}

\subsubsection{IGF-I $m R N A$}

A scattered pattern of IGF-I mRNA expression in all cell types was observed during kidney development (Fig. 2A). The expression pattern at birth was confined to the epithelial cells of both layers of Bowman's capsule and the epithelial cells of cortical tubules. After day P7 a rather drastic decrease was seen in the proximal tubules and at day P14 most of the hybridization signal was found in the peritubular capillaries of the outer medulla and inner cortex (Fig. 4A).

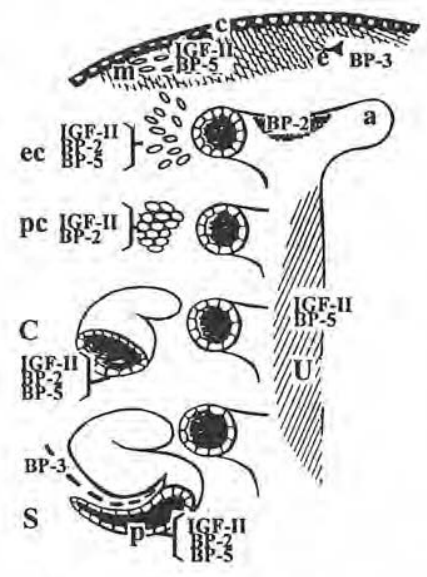

$1 \mathrm{~A}$
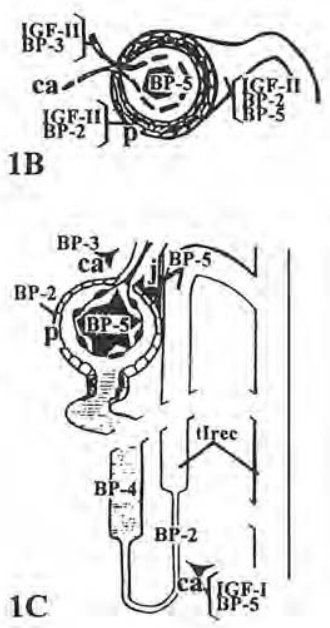

Fig. 1. Schematic illustration of the main expression sites of the IGF system in the developing mouse kidney. (1A) Developmental stages during nephrogenesis including; early condensate (ec); pretubular condensate (pc); comma-shaped body (C); and S-shaped nephron (S). (1B) Developing glomerulus. (1C) Mature nephron. Abbreviations are: c, capsule; m, mesenchyme; e, endothelial cells; a, ampulla; $U$, ureteric bud; $p$, parietal epithelial layer; ca, capillary; j, juxtaglomerular cells.

\subsubsection{IGF-II $m R N A$}

At different fetal stages strong hybridization signals for IGF-II mRNA were detected in differentiating mesenchymal and epithelial cells, as well as endothelial cells. No signals were detected in epithelial cells of the ampulla of the ureteric bud (Fig. 2B). Prominent expression sites were the ureteric bud, parietal and visceral epithelial layers of the nephric bodies (Fig. 2B) and developing proximal tubules (Fig. 4B). After development most cells showed reduction of IGF-II mRNA expression, except for endothelial cells of renal vessels. Faint signals were present in epithelial cells of Bowman's capsule.

\subsubsection{Type I receptor $m R N A$}

The type I receptor mRNA was expressed in all cells of the kidney during fetal development (Fig. 2C). Continuous expression from fetal stage until maturity was observed in visceral and parietal epithelial layers of developing glomeruli and in epithelial cells of distal and collecting tubules (Fig. 4C). Type I receptor mRNA expression was found in proximal tubules until birth and until day P7 the thick limbs of Henle's Loop (Fig. 4C) showed expression. Faint hybridization signals were observed at day P14.

\subsubsection{IGFBP-1 $m R N A$}

Little or no expression was seen in fetal kidney for IGFBP-1 (Fig. 2D). At day P14 faint signals could be observed in some cells of the proximal tubules, distal tubules and the epithelial cells of Bowman's capsule, while strong signals were seen in control liver sections (data not shown). 
Table 2

Expression of IGF system in structures of developing mouse kidney at day E15

\begin{tabular}{|c|c|c|c|c|c|c|c|c|c|}
\hline & IGFI & IGF II & tIrec & BP1 & $\mathrm{BP} 2$ & BP3 & BP4 & BP5 & BP6 \\
\hline Renal capsule & - & + & + & + & - & - & + & ++ & + \\
\hline Early condensate & + & ++ & + & - & + & - & - & ++ & - \\
\hline Pretubular condensate & + & ++ & + & - & + & - & + & - & - \\
\hline Endothelial cells & + & + & + & - & + & ++ & + & + & + \\
\hline Branching area & + & - & + & - & ++ & - & - & - & - \\
\hline \multicolumn{10}{|c|}{ Comma- and $S$-shaped bodies and developing glomeruli } \\
\hline Invading endothelial cells & + & + & + & - & - & ++ & + & - & - \\
\hline Mesangial cells & + & - & + & - & + & - & + & ++ & - \\
\hline Visceral epithelial layer & + & + & + & - & - & - & - & - & - \\
\hline
\end{tabular}

Scoring: - no signal above background; + low abundance; ++ high abundance. Scoring is based on observations in a minimum of three kidney sections obtained from at least two animals.

\subsubsection{IGFBP-2 $m R N A$}

Early stages of developing kidney showed abundant hybridization signals for IGFBP-2 mRNA in the ureteric bud and the surrounding mesenchyme. At day E15 hybridization signals were strong in the branching area of the ureteric bud (Fig. 2E and Fig. 4D) and the parietal epithelial layer of the developing nephric bodies (Fig. 3A). During maturation expression in the glomerulus was expanded to the visceral epithelial layer and at day P14 both layers of Bowman's capsule contributed to the IGFBP-2 mRNA expression pattern. In contrast to a postnatal decrease of hybridization signals in developing proximal tubules, an increase could be observed in the thin limbs of Henle's Loop, being very strong at day P14 (Fig. 4E).

\subsubsection{IGFBP-3 $m R N A$}

Single cells within the population of mesenchymal cells expressed IGFBP-3 mRNA from day E13 on (Fig. 2F). Endothelial cells of the invading capillary loop showed strong expression in the S-shaped nephron stage (Fig. 3B) and during maturation of the glomerulus (Fig. 3D,3F). However in the mature glomerulus no IGFBP-3 mRNA was detected anymore (Fig. 3H). IGFBP- 3 mRNA expression sites at day P14 were the peritubular capillaries in the cortex (Fig. $3 \mathrm{H}$ ) and to a lesser extent those in the medulla.

\subsubsection{IGFBP-4 $m R N A$}

The IGFBP-4 gene was expressed in mesenchymal cells of the developing kidney, showing more signal in the pretubular condensate and in cells enclosed in the nephric bodies and developing glomeruli. No expression was seen in epithelial cells of the ureteric bud and the comma-and S-shaped bodies, while epithelial cells of more developed tubules did express IGFBP-4 mRNA (Fig. 2G). At day P14 the main sites of expression were the proximal tubules including their straight segments (Fig. 4F) and peritubular capillaries in the outer medulla.

\subsubsection{IGFBP-5 $m R N A$}

The epithelial cell layer of the renal capsule and the underlaying outer zone of the metanephric blastema expressed IGFBP-5 mRNA throughout nephrogenesis (Fig. 2H). A very marked expression was observed in mesenchymal cells forming the early condensate (Fig. $2 \mathrm{H}$ ) and those destined to become mesangial cells in developing glomeruli (Fig. 3C). Hybridization signals for IGFBP-5 mRNA were found in epithelial cells of developing proximal tubules (Fig. $4 \mathrm{H}$ ) and of the ureteric bud, except its ampulla (Fig. $2 \mathrm{H}$ ). The expression pattern changed as the kidney matured, showing a decrease in proximal tubules from day $\mathrm{P} 7$ on and a very strong expression arising in peritubular capillaries of the medulla (Fig. 4G). IGFBP-5 mRNA could also be detected in peritubular capillaries and distal tubules of the cortex and abundant expression was present in mesangial cells and in juxtaglomerular cells of the glomeruli (Fig. 3E,3G).

\subsubsection{IGFBP-6 $m R N A$}

IGFBP-6 mRNA was very weakly expressed during nephrogenic stages in epithelial cells (Fig. 2I), but after birth expression could be observed in the visceral epithelial layer and podocytes of developing glomeruli and collecting tubules. At day $\mathrm{P} 14$ no hybridization signals were seen. As positive controls, liver sections showed good hybridization signals. 
Table 3

Expression of IGF system in mouse kidney at day P14

\begin{tabular}{|c|c|c|c|c|c|c|c|c|c|}
\hline & IGF I & IGF II & tIrec & BP1 & BP2 & BP3 & BP4 & BP5 & BP6 \\
\hline \multicolumn{10}{|l|}{ Glomeruli } \\
\hline Capillaries & - & - & - & - & - & - & - & - & - \\
\hline Bowman's capsule & + & + & + & + & ++ & - & - & - & - \\
\hline Juxtaglomerular cells & - & - & - & - & - & - & - & ++ & - \\
\hline \multicolumn{10}{|l|}{ Peritubular capillaries } \\
\hline Outer medulla & ++ & - & - & - & - & + & + & ++ & - \\
\hline Inner medulla & + & - & - & - & - & + & - & ++ & - \\
\hline Distal tubules & + & - & + & + & + & - & - & ++ & - \\
\hline Proximal tubules & - & - & - & + & - & - & ++ & + & - \\
\hline Thick limb of Henle's Loop & + & - & + & - & - & - & + & - & - \\
\hline
\end{tabular}

Scoring: - no signal above background; + low abundance; ++ high abundance. Scoring is based on observations in a minimum of three kidney sections obtained from at least two animals

Renal vessels expressed IGFBP-2,-3,-4 and -5 mRNA throughout development (data not shown).

\subsection{Quantitative $R T-P C R$}

The amount of IGF-II and IGFBP-2 mRNA molecules was high during renal development and for both the same profile was observed: after a significant rise towards birth a postnatal decline started. Lower fetal levels were measured for IGF-I, IGFBP-3 and -5 mRNA and after birth all three began to increase significantly (Fig. 5).

\section{Discussion}

This study has shown well defined spatial and temporal mRNA expression profiles of the members of the IGF system during mouse nephrogenesis. Our presentation is to our knowledge a first combination of data from non radioactive in situ hybridization and quantitative RT-PCR, resulting in optimal cellular localization and reliable quantitation.

As non radioactive in situ hybridization was meant for optimal localization, the colour reaction was stopped when discriminate hybridization signals with maximum intensities were reached. The quantitative RT-PCR compensated for possible variations in probe specificity, UTP content or hybridization conditions and resulted in absolute amounts of mRNA molecules measured.

We have observed distinct expression patterns for the IGFs, the type I receptor and the six IGFBPs throughout kidney development. The widespread moderate expression of type I receptor mRNA is compatible with its IGF-I and -II signal transducing role. On the other hand, the specifically localized expression of the IGFBP mRNAs is supportive for their modulatory role in IGF actions. The half life of the IGFs is prolonged by binding to the IGFBPs, which in circulation function as carrier proteins providing a reservoir of IGFs. In addition, locally produced IGFBPs can regulate the availability of IGFs in the vicinity of their receptors and thus modulate their actions (Liu et al., 1994).

The inverse quantitation profiles for IGF-I and IGFII do suggest their distinct role in different stages of development. High prenatal levels of IGF-II mRNA confined to sites of cellular differentiation support a vital function in nephrogenesis, while increasing levels of IGF-I after birth emphasize its role in postnatal kidney physiology. In the mature kidney localization of IGF-I and type I receptor mRNA in the distal tubules favour the involvement of IGF in transmembrane transport of for instance $\mathrm{Na}^{+}$and tubular inorganic phosphate $(\mathrm{Pi})$, as has been suggested by others (Kobayashi et al., 1995; Caverzasio et al., 1990). Their presence in epithelial cells of the glomerulus might indicate an involvement in regulation of glomerular filtration processes (Hirschberg et al., 1991).

Close interactions of the IGFs and their binding proteins in developing and physiological processes are indicated by their overlapping or adjacent expression sites and parallelling quantitation profiles.

The low hybridization signals for IGFBP-1 mRNA that we detected in the mouse kidney correspond with the findings of Chin et al. (Chin et al., 1994; Chin and Bondy, 1992) in human kidneys. On the other hand, IGFBP-1 is well expressed in rat (Rabkin et al., 1995; Chin and Bondy, 1992; Price et al., 1995) and levels were shown to be influenced by long-term diabetes 
Fetal expression
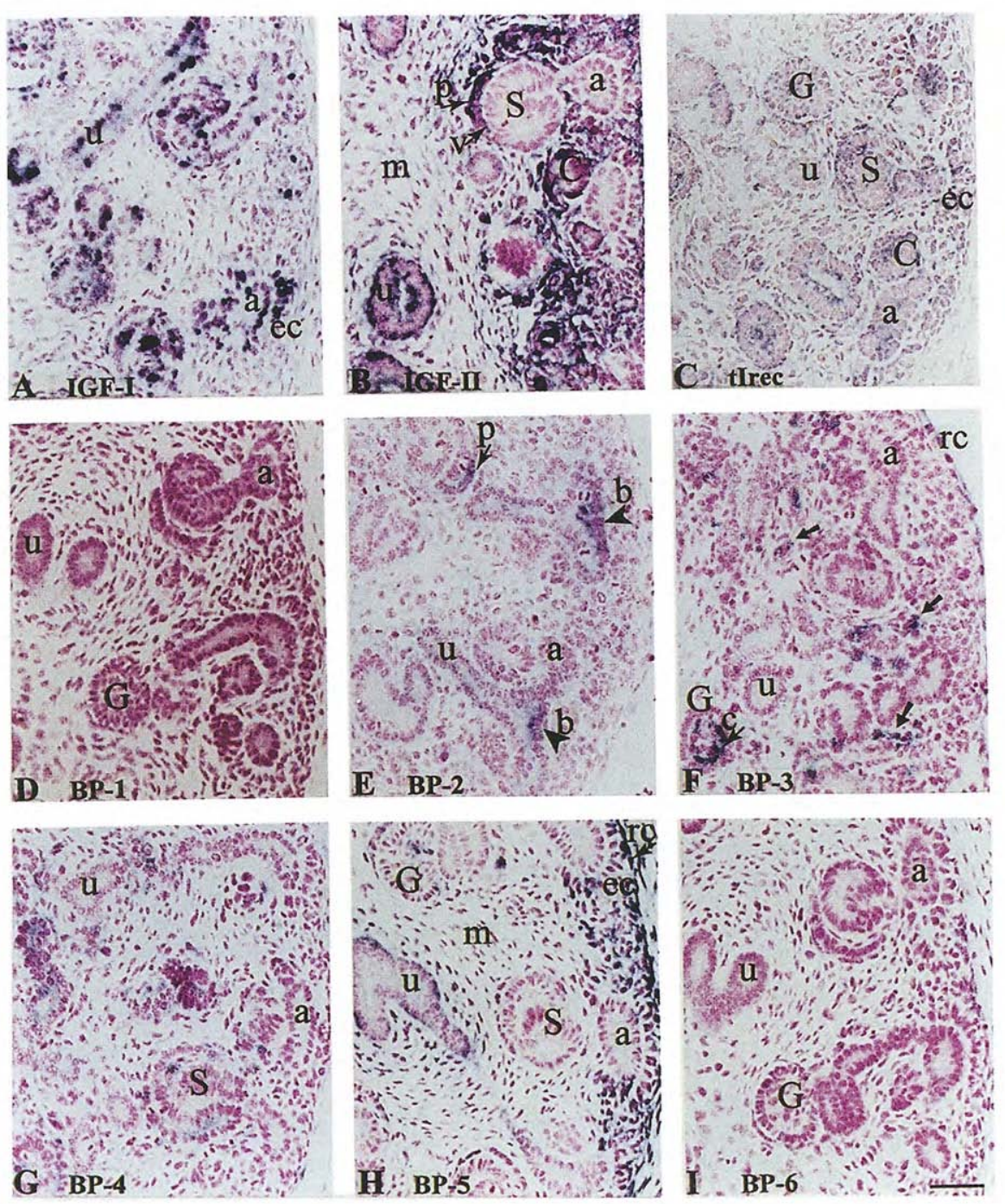

Fig. 2. Photomicrographs of in situ hybridization with DIG-labeled cRNA probes in developing mouse kidneys at day E15. The blue coloured precipitate corresponds to sites of mRNA expression of (A) IGF-I, (B) IGF-II, (C) type I receptor, (D) IGFBP-1, (E) IGFBP-2, (F) IGFBP-3, (G) IGFBP-4, (H) IGFBP-5, (I) IGFBP-6. Abbreviations are: u, ureteric bud; a, ampulla; m, mesenchyme; ec, early condensate; C, Comma-shaped body; S, S-shaped body; G, glomerulus; $p$, parietal epithelial cells; $v$, visceral epithelial cells; $b$, branching area of the ureteric bud; rc, renal capsule; c, capillary loop. Arrows $(\searrow$ ) indicate expression sites of IGFBP-3 in the early capillary network. Scale bar $=50 \mu \mathrm{M}$.

(Landau et al., 1995). These data may indicate a species difference for the role of renal IGFBP-1 in mediating autocrine or paracrine IGF actions.

A striking similarity was observed in the profiles of mRNA levels for IGFBP-2 and IGF-II during nephrogenesis. High prenatal IGFBP-2 mRNA levels which peaked around birth and decreased postnatally, were mimicked by IGF-II. This not only demonstrates the importance of both genes during fetal and perinatal kidney development, but also indicates a close interaction in gene regulation, as has been proposed by others (Delhanty and Han, 1993; Carr et al., 1995). Strong IGFBP-2 hybridization signals were confined to induced differentiating cells in the branching area of the ureteric bud. They support a role for IGFBP-2 in nephrogenic IGF-II actions. Like in rat (Rabkin et al., 1995; Chin and Bondy, 1992; Price et al., 1995) and man (Matsell et al., 1994; Chin et al., 1994; Chin and Bondy, 1992) IGFBP-2 mRNA was confined to the epithelial cells in the mature glomerulus and here its protein might bind circulating or locally produced IGF and facilitate the translocation of vascular IGF into the tubular compartments for renal clearance (Chin and Bondy, 1992). A similar function has been suggested in brain (Bondy et al., 1992). High expression in the thin limbs of Henle's Loop accorded with IGFBP-2 mRNA (Rabkin et al., 1995; Price et al., 1995) and IGFBP-2 protein (Evan et al., 1995) data in rat kidney. By 


\section{Glomerular expression}
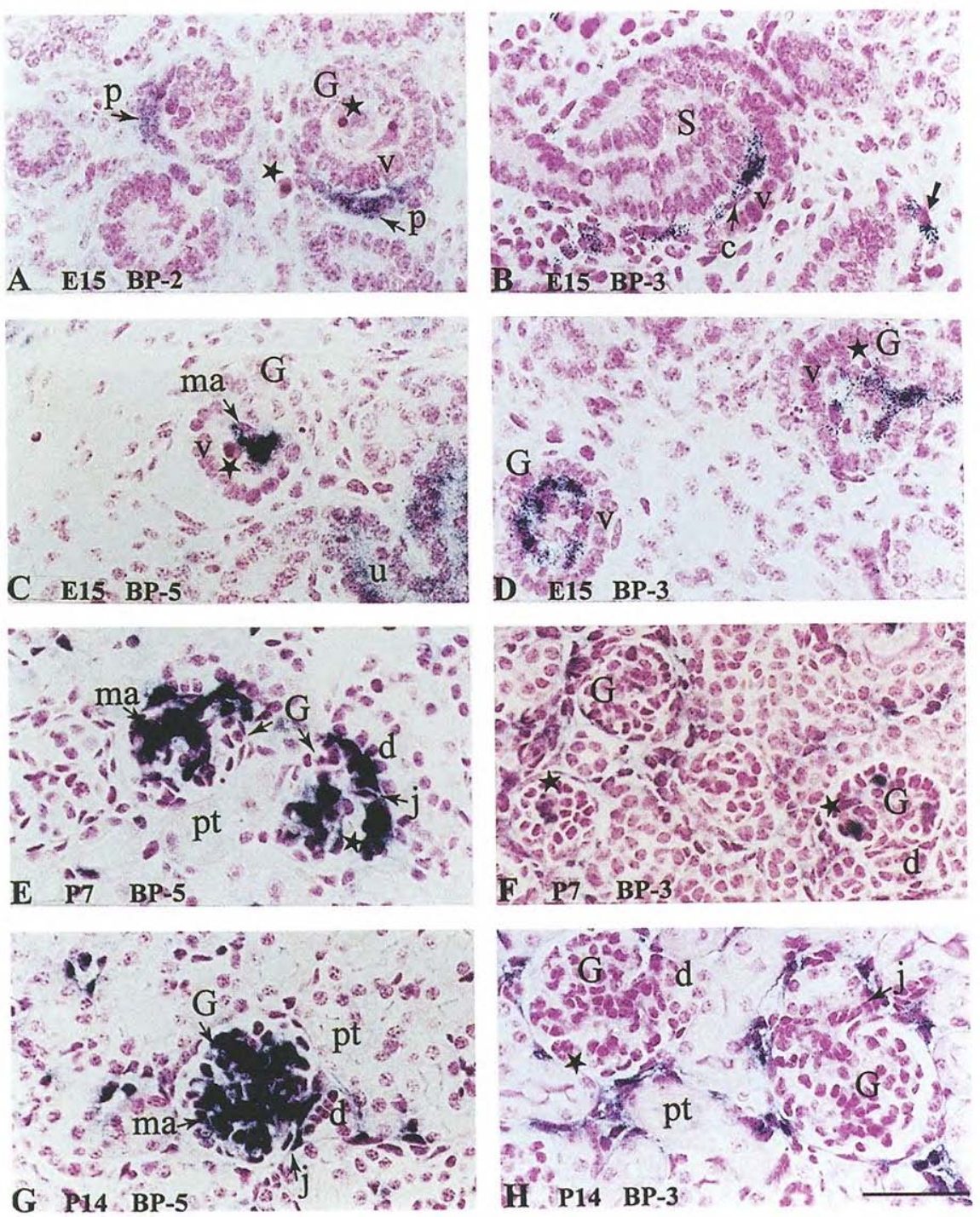

Fig. 3. Photomicrographs of in situ hybridization with DIG-labeled cRNA probes in the developing stages of glomeruli in mouse kidney. (A) IGFBP-2 at day E15, (B, D, F, H) IGFBP-3 at day E15, E15, P7 and P14, respectively. (C, E, G) IGFBP-5 at day E15, P7 and P14, respectively. Abbreviations are: u, ureteric bud; S, S-shaped body; G, glomerulus; p, parietal epithelial cells; v, visceral epithelial cells; c, capillary; ma, mesangial cells; pt, proximal tubule; $d$, distal tubule; $j$, juxtaglomerular cells; $*$ indicates erythrocyte present in capillary; arrow $\searrow$ in (B) points to IGFBP-3 expressing endothelial cell in the mesenchyme. Scale bar $=50 \mu \mathrm{M}$.

influencing the amount of available IGF-II, IGFBP-2 might modulate IGF-II action in $\mathrm{Na}^{+} / \mathrm{H}^{+}$exchange across the membranes of the epithelial cells, as has been demonstrated in cultured proximal tubular cells (Mellas et al., 1986).

The higher IGF-I mRNA levels after birth coincided with increased production of IGFBP- 3 mRNA, which we find in the mouse kidney exclusively located in the capillary system. Our precise cellular localization confirms the suggested expression sites of IGFBP-3 in rat
(Rabkin et al., 1995). Expression of IGFBP-3 in the capillary system may emphasize its main function in being a carrier protein for circulating IGFs. In addition, IGFBP-3 is involved in local actions of IGF, like vascularization (Nakao-Hayashi et al., 1992). The presence of IGFBP-3 in single cells of the mesenchyme, often accompanied by erythrocytes, fits with the assumption that these are endothelial cells, forming the capillary system of the fetal kidney (Pinson Hyink and Abrahamson, 1995). This defined localization correlates 


\section{(Peri-)tubular expression}
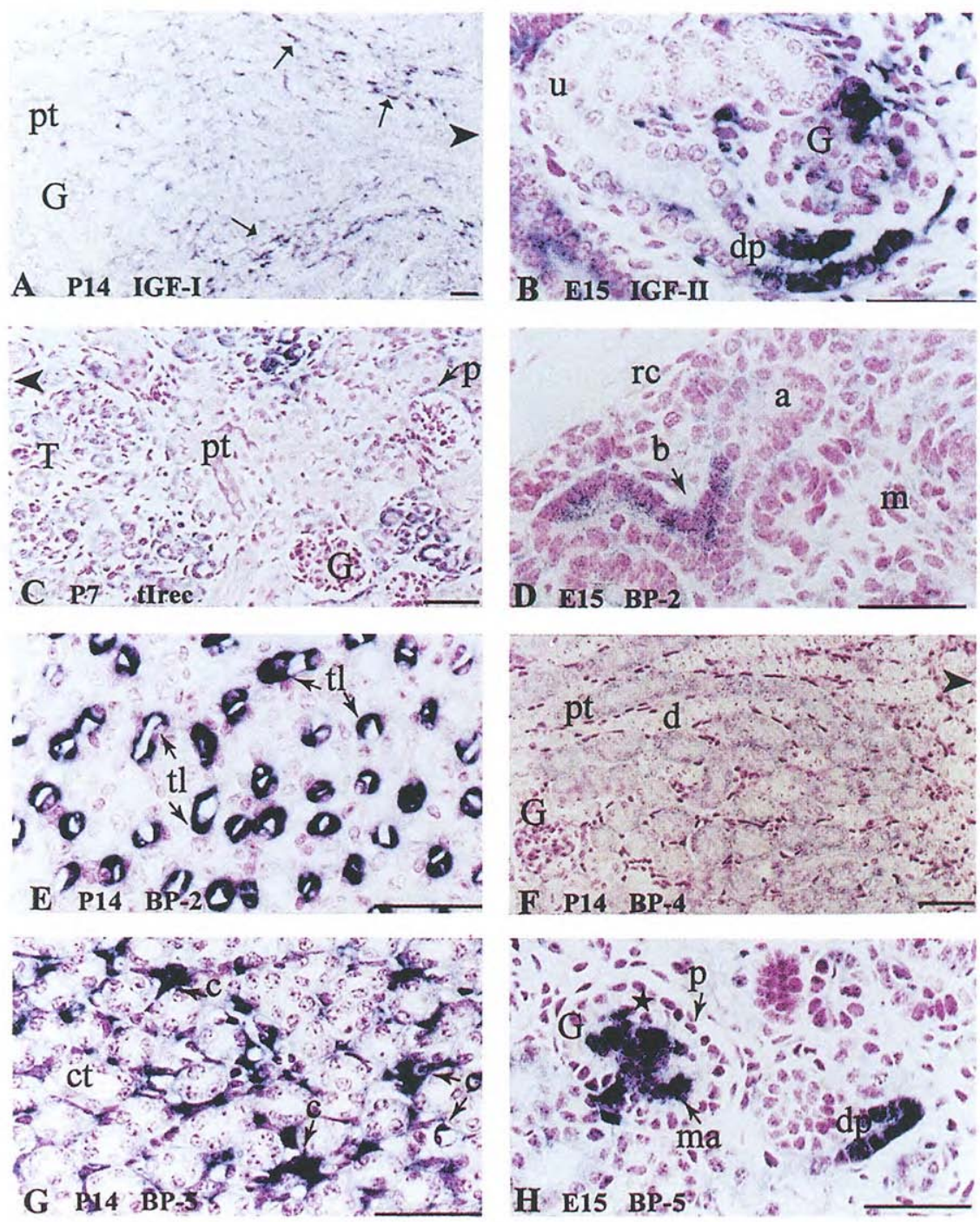

Fig. 4. Photomicrographs of in situ hybridization with DIG-labeled cRNA probes in developing and matured tubules in mouse kidney. (4A) IGF-I at day P14 in peritubular capillaries $(\rightarrow)$ in IC/OM, (4B) IGF-II at day E15, (4C) type I receptor at day P7 in IC/OM, (4D). IGFBP-2 at day E15, (4E) IGFBP-2 at day P14 in the medulla, (4F) IGFBP-4 at day P14, (4G) IGFBP-5 at day P14 in the medulla, (4H) IGFBP-5 at day E15. Abbreviations are: G, glomerulus; pt, proximal tubule; p, parietal epithelial cells; T, thick limb of Henle's loop; u, ureteric bud; dp, developing proximal tubule; $d$, distal tubule; ma, mesangial cells; ct, collecting tubule; $c$, peritubular capillary; rc, renal capsule; b, branching area of the ureteric bud; m, mesenchyme; tl, thin limb of Henle's loop; $\$$, indicates erythrocytes present in capillary. Arrowhead points to the medullary region. Scale bar $=50 \mu \mathrm{M}$.

well with the observed expression in human nephrogenic mesenchyme (Matsell et al., 1994). Until maturation IGFBP-3 mRNA was expressed in the invading endothelial cells, forming the capillary loop of the developing glomerulus. Besides its possible role here in vascularization, IGFBP-3 might also act as a provider of IGFs to have their effect on the formation of the glomerular basement membrane (GBM) and the production of the extracellular matrix (ECM) in the mesangial cells (Pricci et al., 1996). IGFBP-3 was no longer expressed in the mature glomerulus, however during severe glomerulosclerosis in diabetic growth hormone transgenic mice IGFBP-3 mRNA is again expressed in the capillaries of the glomeruli (manuscript in preparation). This resumption of IGFBP-3 mRNA expression could be a result of elevated IGF-I levels (Clemmons et al., 1989; Bach and Jerums, 1990; Flyvbjerg et al., 1990) perhaps to enhance IGF action (Blum et al., 1989) in the expansion of mesangial ECM (Doi et al., 1989).

Expression patterns for IGFBP-5 mRNA in mouse were similar to those in man (Matsell et al., 1994; Chin 
et al., 1994) and rat (Rabkin et al., 1995; Price et al., 1995). In the developing mouse kidney, IGFBP-5 mRNA co-localized with IGF-II mRNA at sites of cellular differentiation. This might imply a role for IGFBP-5 in potentiating IGF-II action as also has been described for osteoblasts in vitro (Andress and Birnbaum, 1992). Involvement in functional processes in the kidney is made likely by the increase in mRNA levels after birth. High IGFBP-5 mRNA expression in mesangial cells persisted in the mature glomerulus and expanded with the migration of the mesangial cells into the juxtaglomerular cells. Taking into account that IGFs have a stimulatory effect on the glomerular filtration rate (GFR) (Hirschberg et al., 1991), we might assume a mediating role for IGFBP-5 in this process. In vitro studies showed that ionic strength influences IGFBP-5 binding to ECM. Bound to ECM IGFBP-5 has a reduced affinity for IGFs, while being in solution its affinity increases (Jones et al., 1993). In this way IGFBP-5 can influence the availability of IGFs for their receptors and as a result the IGF actions in the vicinity of the glomerular filtration apparatus. The IGFBP-5 mRNA expression described in rat (Rabkin et al., 1995; Price et al., 1995) and human (Matsell et al., 1994; Chin
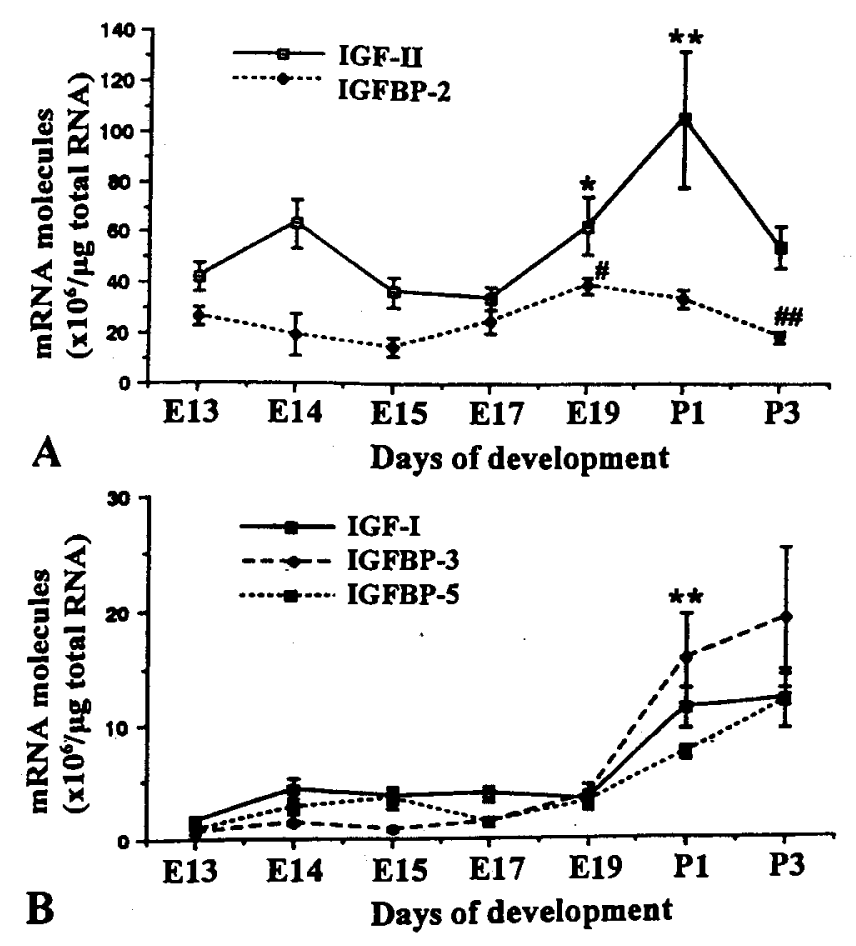

Fig. 5. (5A) Quantitation profiles for mRNA of IGF-II and IGFBP-2 during mouse kidney development. Data represent the means $(n=4-$ 6) \pm S.E.M. ${ }^{* *}$ Significant compared to E17 $(P<0.02)$; not significant compared to $\mathrm{P} 3(P<0.06) .{ }^{*}$ Significant compared to E17 $(P<0.03)$. \# \# Significant compared to P1 $(P<0.02)$. \# Significant compared to E17 and P3 $(P<0.05)$. (5B). Quantitation profiles for mRNA of IGF-I, IGFBP-3 and -5 during mouse kidney development. Data represent the means $(n=4-6) \pm$ S.E.M. ${ }^{* *}$ Significant compared to E19 for all genes $(P<0.02)$. et al., 1994) medullary interstitium supports our defined localization in the peritubular capillaries of the medulla. The presence here of IGFBP-5 indicates an involvement in the IGF stimulated ion transport and exchange in the surrounding tubules (Zumkeller and Scofield, 1992).

In summary, we have shown that a combination of non radioactive in situ hybridization and quantitative RT-PCR results in a well defined localization and quantitation of mRNA expression. Our results demonstrate that during mouse kidney development each member of the IGF system has its specific mRNA expression pattern and altering mRNA levels. Distinct roles for each of them can be proposed in renal development and physiology and therefore our findings might be helpful to interpret observations of pathophysiological conditions.

\section{Acknowledgements}

This project was supported by the Swart-Van Essen Foundation. R.R. Rosato was supported by grant CHRX-CT94-0556 of the E.E.C. Human Capital and Mobility Program and J.W. van Neck was supported by the Netherlands Organisation for Scientific Research, grant \# 901-28-088. The authors wish to thank Professor D. Tibboel for critically reading the manuscript, M. Vermey for excellent assistance in histological techniques and F. Van der Panne for assistance in photography.

\section{References}

Andress, D.L., Birnbaum, R.S., 1992. Human osteoblast-derived insulin-like growth factor (IGF) binding protein-5 stimulates osteoblast mitogenesis and potentiates IGF action. J. Biol. Chem. 267, 22467-22472.

Bach, L.A., Jerums, G., 1990. Effect of puberty on initial kidney growth and rise in kidney IGF-I in diabetic rats. Diabetes 39 , $557-562$.

Blazer-Yost, B.L., Cox, M., 1988. Insulin-like growth factor I stimulates renal epithelial $\mathrm{Na}^{+}$transport. Am. J. Physiol. 255, C413C417.

Blazer-Yost, B.L., Cox, M., Furlanetto, R., 1989. Insulin and IGF-I receptor mediated $\mathrm{Na}^{+}$transport in toad urinary bladders. Am. J. Physiol. 257, C612-C620.

Blum, W.F., Jenne, E.W., Reppin, F., Kietzman, K., Ranke, M.B., Bierich, J.R., 1989. Insulin-like growth factor I (IGF-I)-binding protein complex is a better mitogen than free IGF-I. Endocrinology $125,766-772$.

Bondy, C.A., Werner, H., Roberts, C.T., LeRoith, D., 1990. Cellular pattern of insulin-like growth factor-I (IGF-I) and type I receptor gene expression. Mol. Endocrinol. 4, 1386-1398.

Bondy, C.A., Werner, H., Roberts, C.T., LeRoith, D., 1992. The cellular pattern of type-I IGF receptor gene expression during the maturation of the rat brain: comparison with IGF-I and IGF-II. Neuroscience 46, 909-923. 
Carr, J.M., Owens, J.A., Grant, P.A., Walton, P.E., Owens, P.C., Wallace, J.C., 1995. Circulating insulin-like growth factors (IGFs), IGF-binding proteins (IGFBPs) and tissue mRNA levels of IGFBP-2 and IGFBP-4 in the ovine fetus. J. Endocrinol. 145, $545-557$.

Caverzasio, J., Montessuit, C., Bonjour, J., 1990. Stimulatory effect of insulin-like growth factor I on renal Pi transport and plasma 1,25-dihydroxyvitamin $\mathrm{D}_{3}$. Endocrinology 127, 453-459.

Chin, E., Zhou, J., Bondy, C., 1992. Anatomical relationships in the patterns of insulin- like growth factor (IGF)-I, IGF binding protein-1, and IGF-I receptor gene expression in the rat kidney. Endocrinology 130, 3237-3245.

Chin, E., Michels, K., Bondy, C.A., 1994. Partition of insulin-like growth factor (IGF)-binding sites between the IGF-I and IGF-II receptors and IGF- binding proteins in the human kidney. J. Clin. Endocrinol. Metab. 78, 156-164.

Chin, E., Bondy, C., 1992. Insulin-like growth factor system gene expression in the human kidney. J. Clin. Endocrinol. Metab. 75, 962-968.

Chomczynski, P., Sacchi, N., 1987. Single-step method of RNA isolation by acid guanidinium thiocyanate-phenol-chloroform extraction. Anal. Biochem. 162, 156-159.

Clemmons, D.R., Thissen, J.P., Maes, M., Ketelslegers, J.M., Underwood, L.E., 1989. Insulin-like growth factor-I (IGF-I) infusion into hypophysectomized or protein-deprived rats induces specific IGF binding proteins in serum. Endocrinology 125, 2967-2972.

Delhanty, P.J.D., Han, V.K.M., 1993. The expression of insulin-like growth factor (IGF)-binding protein-2 and IGF-II genes in the tissues of the developing ovine fetus. Endocrinology 132 (1), $41-52$.

Doi, T., Striker, L.J., Elliot, S.J., Conti, F.G., Striker, G.E., 1989. Insulin-like growth factor-I is a progression factor for human mesangial cells. Am. J. Pathol. 134, 395-404.

Evan, A.P., Henry, D.P., Connors, B.A., Summerlin, P., Lee, W.H., 1995. Analysis of insulin-like growth factors (IGF)-I, and -II, type II IGF receptor and IGF-binding protein- 2 mRNA and peptide levels in normal and nephrectomized rat kidney. Kidney Int. 48, $1517-1529$.

Flyvbjerg, A., Frystyk, J., Marshall, M., 1990. Additive increase in kidney insulin-like growth factor I and initial renal enlargement in uninephrectomized-diabetic rats. Horm. Metab. Res. 22, 516-520.

Hammerman, M.R., 1995. Growth factors in renal development. Semin. Nephrol. 15 (4), 291-299.

Hirschberg, R., Kopple, J., Blantz, R., Tucker, B., 1991. Effects of recombinant human insulin-like growth factor I on glomerular dynamics in the rat. J. Clin. Invest. 87, 1200-1206.

Hirschberg, R., Brunori, G., Kopple, J.D., Guler, H.P., 1993. Effects of insulin-like growth factor on renal function in normal men. Kidney Int. 43, 387-397.

Jones, J.I., Gockerman, A., Busby, Jr. W.H., Camacho-Hubner, C., Clemmons, D.R., 1993. Extracellular matrix contains insulin-like growth factor binding protein-5: Potentiation of the effects of IGF-I. J. Cell Biol. 121, 679-687.

Kobayashi, S., Clemmons, D.R., Nogami, H., Roy, A.K., Venkatachalam, M.A., 1995. Tubular hypertrophy due to work load induced by furosemide is associated with increases of IGF-I and IGFBP-1. Kidney Int. 47, 818-828.

Landau, D., Chin, E., Bondy, C., Domene, H., Roberts, C.T., Gronbaek, H., Fly.vbjerg, A., LeRoith, D., 1995. Expression of insulin-like growth factor binding proteins in the rat kidney: effects of long-term diabetes. Endocrinology 136, 1835-1842.

Liu, Z.Z., Wada, J., Alvares, K., Kumar, A., Wallner, E.I., Kanwar, Y.S., 1993. Distribution and relevance of insulin-like growth
factor-I receptor in metanephric development. Kidney Int. 44 , $1242-1250$

Liu, Z.Z., Kumar, A., Wallner, E.I., Wada, J., Carone, F.A., Kanwar, Y.S., 1994. Trophic effect of insulin-like growth factor-I on metanephric development: relationship to proteoglycans. Eur. J. Cell Biol. 65, 378-391.

Matsell, D.G., Delhanty, P.J.D., Stepaniuk, O., Goodyer, C., Han, V.K.H., 1994. Expression of insulin-like growth factor and binding protein genes during nephrogenesis. Kidney Int. 46, 10311042.

Mellas, J., Gavin, J.R., Hammerman, M.R., 1986. Multiplicationstimulating activity-induced alkalinization of canine renal proximal tubular cells. J. Biol. Chem. 261, 14437-14442.

Nakao-Hayashi, J., Ito, H., Kanayasu, T., Morita, I., Murota, S., 1992. Stimulatory effects of insulin and insulin-like growth factor I on migration and tube formation by vascular endothelial cells. Atherosclerosis 92, 141-149.

Pane, F., Salera, A., Mostarda, I., Salvatore, F., Sacchetti, L., 1995. Estimation of extreme low amounts of single mRNAs by quantitative noncompetitive reverse transcription-polymerase chain reaction assay in biological specimens from normal and neoplastic cells. Anal. Biochem. 225, 362-366.

Pinson Hyink, D., Abrahamson, D.R., 1995. Origin of the glomerular vasculature in the developing kidney. Semin. Nephrol. 15, 300314.

Pricci, F., Pugliese, G., Romano, G., Romeo, G., Locuratolo, N., Pugliese, F., Mené, P., Galli, G., Casini, A., Rotella, C.M., Mario, U.D., 1996. Insulin-like growth factors I and II stimulate extracellular matrix production in human glomerular mesangial cells. Comparison with transforming growth factor- $\beta$. Endocrinology $137,879-885$.

Price, G.J., Berka, J.L., Edmondson, S.R., Werther, G.A., Bach, L.A., 1995. Localization of mRNAs for insulin-like growth factor binding proteins 1 to 6 in rat kidney. Kidney Int. 48, 402-411.

Quigly, R., Baum, M., 1991. Effects of growth hormone and insulinlike growth factor I on rabbit proximal convoluted tubule transport. J. Clin. Invest. 88, 368-374.

Rabkin, R., Brody, M., Lu, L.H., Chan, C., Shaheen, A.M., Gillett, N., 1995. Expression of the genes encoding the rat renal Insulinlike growth factor-I system. J. Am. Soc. Nephrol. 6, 1511-1518.

Rogers, S.A., Hammerman, M.R., 1989. Growth hormone directly stimulates gluconeogenesis in canine proximal tubule. Am. J. Physiol. 257, E751-E756.

Rogers, S.A., Ryan, G., Hammerman, M.R., 1991. Insulin-like growth factors I and II are produced in the metanephros and are required for growth and development in vitro. J. Cell Biol. 113, $1447-1453$

Saxen, L., Sariola, H., 1987. Early organogenesis of the kidney. Pediatr. Nephrol. 1, 385-392.

Saxen L, Organogenesis of the Kidney, Cambridge University Press, Cambridge, 1987

Schuller, A.G.P., Zwarthoff, E.C., Drop, S.L.S., 1993. Gene expression of the six insulin-like growth factor binding proteins (IGF$\mathrm{BPs})$ in the mouse conceptus during mid- and late-gestation. Endocrinology 132, 2544-2550.

Schuller, A.G.P., Groffen, C., VanNeck, J.W., Zwarthoff, E.C., Drop, S.L.S., 1994. cDNA cloning and mRNA expression of the six mouse insulin- like growth factor binding proteins. Mol. Cell. Endocrinol. 104, 57-66.

Zumkeller, W., Scofield, P., 1992. The role of insulin-like growth factors and IGF-binding proteins in the physiological and pathological processes of the kidney. Virchows Arch. B Cell Pathol. 62, $207-220$ 